\title{
Consensus of the Amapá society of implantodontics on the criteria for choosing a bone graft.
}

\author{
Antônio Santos Araújo (1) e Silvana Rauber (1)
}

\section{ORIGINAL ARTICLE}

\section{ABSTRACT}

A bone graft may be used in a variety of clinically practiced implant surgeries, namely, guided bone regeneration, extraction socket preservation or reconstruction, ridge augmentation, and sinus membrane elevation. The bone graft is of various types depending on the material, for instance, autogenous bone graft, allograft, xenograft, alloplastic graft, and autogenous bone graft with demineralized dentin matrix, which may be used alone or with other materials. Bioactive agents that promote bone formation, such as recombinant human bone morphogenetic protein-2 (rhBMP-2), have been shown to exhibit a clinically beneficial effect on bone regeneration. Here, we intend to present surgical guidelines for bone grafts and criteria for selection of bone graft materials by referring to evidence-based studies and recent lectures on the subject of 'bone grafts for implant dentistry' at the Amapá society of implantodontics, 2020.

Keywords: Bone graft, Dental Implant, Consensus, Amapá society of implantodontics; 


\section{Consenso da sociedade Amapaense de implantodontia sobre os critérios de escolha do enxerto ósseo.}

\section{RESUMO}

Um enxerto ósseo pode ser usado em uma variedade de cirurgias de implante praticadas clinicamente, a saber, regeneração óssea guiada, preservação ou reconstrução do alvéolo de extração, aumento da crista e elevação da membrana sinusal. O enxerto ósseo é de vários tipos dependendo do material, por exemplo, enxerto ósseo autógeno, aloenxerto, xenoenxerto, enxerto aloplástico e enxerto ósseo autógeno com matriz dentinária desmineralizada, que podem ser utilizados isoladamente ou com outros materiais. Os agentes bioativos que promovem a formação óssea, como a proteína- 2 morfogenética óssea humana recombinante (rhBMP-2), mostraram exibir um efeito clinicamente benéfico na regeneração óssea. Aqui, pretendemos apresentar diretrizes cirúrgicas para enxertos ósseos e critérios para seleção de materiais de enxerto ósseo, referindo-nos a estudos baseados em evidências e palestras recentes sobre o tema 'enxertos ósseos para implantodontia' na sociedade de implantodontia do Amapá, 2020.

Palavras-chaves: Enxerto ósseo, Implante Dentário, Consenso, Sociedade Amapaense de Implantodontia.

Instituição afiliada: 1- Amapá society of implantodontics

Dados da publicação: Artigo recebido em 01 de Setembro, revisado em 10 de Setembro, aceito para publicação em 20 de Setembro e publicado em 30 de Setembro.

DOI: https://doi.org/10.36557/2674-8169.2020v2n10p10-20

Antônio Santos Araújoauaraujo123@gmail.com 


\section{INTRODUCTION}

Implant surgery without any bone graft results in better prognosis than the surgery with bone graft. In principle, minimally invasive surgery should be conducted, and the research community continues to develop it. Stability of the short-length implant in the mandible has already been confirmed. It has also been reported that the stability of the longlength implant in the maxilla with sinus bone graft is not significantly different from that of the short-length implant in the maxila (1). On the other hand, studies have shown that implants do not show significant difference between the sinus elevation with bone graft and without bone graft. However, proper bone formation is achieved when maxillary sinus elevation is performed without a bone graft. It is safe to perform the sinus elevation without the bone graft in the presence of minimal alveolar bone which leads to initial implant stabilization. This technique should be performed without perforating the sinus membrane $(2,3)$.

On the other hand, the situations requiring bone grafting can be summarized as follows. (1) If the residual bone mass is absolutely insufficient, (2) For the purpose of preventing the resorption of the labial alveolar bone in the anterior portion requiring esthetics or increasing the bone thickness, (3) Since the loss of bone wall is significant after extraction, it is important to create a favorable environment for secondary implant placement, (4) To preserve bone resorption in the extraction socket. The bone graft can be of various types depending on the material, namely, autograft, allograft, xenograft, alloplastic material graft, and autogenous demineralized dentin matrix. In recent years, bioactive bone regenerative agents, such as recombinant human bone morphogenetic protein-2 (rhBMP-2) have been used in many clinical cases to promote bone formation (4-7). Clinicians are most interested in selecting the correct kind of bone graft material in the cases where the bone graft is needed, however, no such clear criteria are described in the literature. Therefore, we summarize the criteria for selection of bone graft materials by referring to the academic papers and famous Korean clinician's lectures by The Korean Academy of Implant Dentistry.

\section{SELECTION OF BONE GRAFT MATERIALS ON THE BASIS OF ENVIRONMENT}

Bone grafts are often required during an implant surgery. Their material must be selected depending on the surgical conditions. The following is the summary of the evidencebased theory or the consensus of clinicians with respect to bone-graft selection:

\section{Extraction socket preservation (ridge preservation) or extraction socket reconstruction}

1) If all the surrounding bone walls, namely, the buccal, palatal (lingual), mesial, and distal, are healthy after tooth extraction, then a bone graft in the extracted socket is not recommended as natural bone healing may perform well (8). 
2) If the bone wall of extraction socket is damaged to a great extent, then it may lead to quick penetration of soft tissue into the extraction socket, thereby hampering the bone healing. In many cases, buccal walls are destroyed due to a trauma or periodontitis; a bone graft is recommended in such cases for the reconstruction of damaged bone wall in the anterior teeth area for the required esthetics $(9,10)$.

3) Selection of bone graft materials

(1) In the anterior teeth area which requires aesthetics, a biocompatible material is recommended owing to its slow or rare resorption to maintain the buccal (labial) bone thickness. Xenograft such as anorganic bovine bone, porcine bone, equine bone, and alloplastic material graft such as hydroxyapatite are also considered as good options (11).

(2) In cases with severe or multiple wall defects, an autogenous bone graft is recommended owing to its excellent bone regeneration property when used alone or with other bone graft materials. The use of rhBMP-2 which can promote bone formation in combination with the appropriate scaffold has also been reported to yield good results (12).

(3) However, except for an autogenous bone graft, superiority of other bone grafts, such as allograft, xenograft, alloplastic graft over other each other has not yet been established $(13,14)$.

\section{Guided bone regeneration (GBR) (15-17)}

1) The GBR for reconstruction in cases with fenestration defect can yield an appreciably better bone regeneration than the cases with dehiscence defect.

2) Leaving less than $2 \mathrm{~mm}$ of a dehiscent wound without GBR yields better results.

3) GBR may be useful for small defects. All the biocompatible bone graft materials can be used in such cases without necessitating the use of a barrier membrane.

4) If the defect size is large, it is better to use the autogenous bone together. The implant surface is filled with autogenous bone, while the outer area of the defect is covered by other bone substitutes which exhibit late resorption to finally recover a barrier membrane. The use of rhBMP-2, which promotes bone formation, in combination with an appropriate scaffold also yields good results.

\section{Ridge augmentation}

Horizontal (lateral) ridge augmentation produces better effects than vertical ridge augmentation. The vertical ridge augmentation using the onlay technique tends to result in a dehiscent wound and loss of bone graft material. Thus, an interpositional bone graft can be 
used to prevent the abovementioned problems. However, it is associated with surgical difficulties and nerve-damaging risks.

1) Blood supply to the bone graft is provided through remains of the alveolar bone and soft tissue of the upper part post reconstruction process in 1-wall defect cases. So, it is difficult to obtain sufficient bone augmentation that may result in complications, such as wound dehiscence, bone loss, and infection. Therefore, it is recommended to include an additional autogenous bone graft to achieve good clinical results $(18,19)$.

2) Clinical outcome and amount of augmentation are not significantly different between the cases with block bone graft and particulate bone graft $(20,21)$.

3) It is safe to aim for an augmentation up to $3 \sim 4 \mathrm{~mm}$. However, for an increase of more than $4 \mathrm{~mm}$, distraction osteogenesis or interpositional bone graft is recommended22).

4) If the volume of augmentation is large, a mixture of autogenous bone graft and other bone graft materials is recommended. However, no specific bone graft material has been proved to be superior. The use of rhBMP-2 which can promote bone formation in combination with an appropriate scaffold also yields good results $(12,23-25)$.

\section{Sinus bone graft}

If the residual bone height is greater than $5 \mathrm{~mm}$, the surgeons can choose their preferred procedure because it is known that there is no difference between the crestal and lateral approach during sinus elevation and bone graft. There are also numerous studies that report no differences between procedures with bone graft and without bone graft, and also the type of bone graft material. However, if the residual bone height is less than $5 \mathrm{~mm}$, the lateral window technique can produce more stable results. The simultaneous implant surgery or delayed implant placement can be determined according to the initial stability of the implant. Generally, if it is less than $3 \mathrm{~mm}$, delayed implant placement is more stable whereas if it is between $3 \mathrm{~mm}$ and $5 \mathrm{~mm}$, simultaneous implant placement is believed to yield a good result.

1) Any biocompatible material can yield good results, if the maxillary sinus is healthy, and there is no large perforation (more than $1 \mathrm{~cm}$ ) in the sinus membrane during the surgery (26-28).

2) Following are the cases in which an autogenous bone graft should be used29-32). It has been reported that if an autogenous bone graft is used in the inferior sinus, and xenograft or alloplastic graft is used in the superior sinus, good long-term results can be obtained.

(1) In case of a wide edentulous area extending in the maxillary region, a massive bone graft is needed.

(2) In case of a large perforation $(>1 \mathrm{~cm})$ of sinus membrane. 
(3) In case of simultaneous reconstruction for oro-antral fistula.

(4) In case of poor blood flow and presence of scar-like tissues due to maxillary sinusitis, history of sinus operation, and failure of sinus bone graft.

\section{CONCLUSION}

Criteria for selection of implant surgery, type of bone graft, and bone graft material on the basis of lectures at the Amapá society of implantodontics, 2020 and evidence-based sufficient academic backgrounds can be summarized as follows $(33,34)$ :

1. Major bone grafts are not recommended in a case with severe atrophic mandibular recession. It is recommended to resolve the problems with a short-length implant whenever possible.

2. A bone graft is not needed in a freshly extracted socket. However, in a case with severe bone wall defects, extraction socket preservation or reconstruction using a bone graft is recommended to prevent penetration of soft tissue and for creation of good conditions for delayed implants.

3. The biocompatible bone substitutes in a sinus bone graft can be used instead of an autogenous bone graft, which shows good bone healing. However, in cases where the condition of maxillary sinus is poor or the range of sinus bone graft is wide, autogenous bone graft should be used to enhance bone healing.

4. Although, distraction osteogenesis and vertical ridge augmentation can be used to vertically increase the alveolar bone; their effect remains unclear.

5. It is recommended to include an autogenous bone graft in ridge augmentation of 1wall defect.

6. In case of large defects around dental implants, an autogenous bone should be grafted in the implant surface, while other bone substitutes with late resorption are present in the outer area of the defect to finally cover a barrier membrane.

7. The use of rhBMP-2 with bone substitutes has been found to be useful in promoting bone formation. However, the effects of other growth factors, such as platelet rich plasma (PRP), are not clear. The selection of bone graft materials and bone grafts is important. The following criteria need to be followed to achieve a successful bone graft.

1. Strict sterilization and prevention of infection.

2. Complete primary closure of soft tissue.

3. If there is a wide range of defects, an autogenous bone graft should be included. 
4. Rigid fixation of grafted materials.

5. Presence of rich nutritional blood supply. 6. Minimizing the load on the bone-grafted area.

\section{REFERENCES}

1. Sanz M, Donos N, Alcoforado G, et al. Therapeutic concepts and methods for improving dental implant outcomes. Summary and consensus statements. The 4th EAO Consensus Conference 2015. Clin Oral Implants Re. 2015;26 Suppl 11:202-6.

2. Duan DH, Fu JH, Qi W, et al. Graft-Free Maxillary Sinus Floor Elevation: A Systematic Review and Meta-Analysis. J Periodontol 2017;88(6):550-564.

3. Silva LD, de Lima VN, Faverani LP, et al. Maxillary sinus lift surgery-with or without graft material? A systematic review. Int J Oral Maxillofac Surg 2016;45(12):1570-1576.

4. Pang KM, Um IW, Kim YK, et al. Autogenous demineralized dentin matrix from extracted tooth for the augmentation of alveolar bone defect: a prospective randomized clinical trial in comparison with anorganic bovine bone. Clin Oral Implants Res 2017;28(7):809-815.

5. Kim SY, Kim YK, Park YH, et al. Evaluation of the Healing Potential of Demineralized Dentin Matrix Fixed with Recombinant Human Bone Morphogenetic Protein-2 in Bone Grafts. Materials (Basel) 2017;10(9).

6. Kim YK, Yun PY, Kim SG, Lim SC. Analysis of the healing process in sinus bone grafting using various grafting materials. Oral Surg Oral Med Oral Pathol Oral Radiol Endod 2009;107(2): 204-11.

7. Jo SH, Kim YK, Choi YH. Histological Evaluation of the Healing Process of Various Bone Graft Materials after Engraftment into the Human Body. Materials (Basel) 2018;11(5).

8. Ten Heggeler JM, Slot DE, Van der Weijden GA. Effect of socket preservation therapies following tooth extraction in non-molar regions in humans: a systematic review. Clin Oral Implants Res 2011;22(8):779-88.

9. Sanz M, Donos N, Alcoforado G, et al. Therapeutic concepts and methods for improving dental implant outcomes. Summary and consensus statements. The 4th EAO Consensus Conference 2015. Clin Oral Implants Res. 2015;26 Suppl 11: 202-6.

10. Jambhekar S, Kernen F, Bidra AS. Clinical and histologic outcomes of socket grafting after flapless tooth extraction: a systematic review of randomized controlled clinical trials. J

Prosthet Dent 2015;113(5):371-82. 
11. Horowitz R, Holtzclaw D, Rosen PS. A review on alveolar ridge preservation following tooth extraction. J Evid Based Dent Pract 2012;12(3 Suppl):149-60.

12. Wallace SC, Pikos MA, Prasad H. De novo bone regeneration in human extraction sites using recombinant human bone morphogenetic protein-2/ACS: a clinical, histomorphometric, densitometric, and 3-dimensional cone-beam computerized tomographic scan evaluation. Implant Dent 2014;23(2): 132-7.

13. Barallat L, Ruíz-Magaz V, Levi PA Jr, et al. Histomorphometric results in ridge preservation procedures comparing various graft materials in extraction sockets with nongrafted sockets in humans: a systematic review. Implant Dent 2014;23(5): 539-54.

14. Borg TD, Mealey BL. Histologic healing following tooth extraction with ridge preservation using mineralized versus combined mineralized-demineralized freeze-dried bone allograft: a randomized controlled clinical trial. J Periodontol 2015; 86(3):348-55.

15. Jung RE, Herzog $M$, Wolleb $\mathrm{K}$, et al. A randomized controlled clinical trial comparing small buccal dehiscence defects around dental implants treated with guided bone regeneration or left for spontaneous healing. Clin Oral Implants Res 2017;28(3):348-354.

16. Shin YS, Seo JY, Oh SH, et al. The effects of ErhBMP-2-/ EGCG-coated BCP bone substitute on dehiscence around dental implants in dogs. Oral Dis. 2014 Apr;20(3):281-7.

17. Smiler DG. Advances in endosseous implants: the 'sandwich' split cortical graft for dental implant placement. Dent Implantol Update. 2000;11(7):49-53.

18. Chappuis V, Cavusoglu Y, Buser D, von Arx T. Lateral Ridge Augmentation Using Autogenous Block Grafts and Guided Bone Regeneration: A 10-Year Prospective Case Series Study. Clin Implant Dent Relat Res 2017;19(1):85-96.

19. Urban IA, Lozada JL, Jovanovic SA, et al. Vertical ridge augmentation with titaniumreinforced, dense-PTFE membranes and a combination of particulated autogenous bone and anorganic bovine bone-derived mineral: a prospective case series in 19 patients. Int J Oral Maxillofac Implants 2014;29(1): 185-93.

20. Chiapasco M, Abati S, Romeo E, Vogel G. Clinical outcome of autogenous bone blocks or guided bone regeneration with e-PTFE membranes for the reconstruction of narrow edentulous ridges. Clin Oral Implants Res 1999;10(4):278-88.

21. Sanz-Sánchez I, Ortiz-Vigón A, Sanz-Martín I, et al. Effectiveness of Lateral Bone Augmentation on the Alveolar Crest Dimension: A Systematic Review and Meta-analysis. J Dent Res 2015;94(9 Suppl):128S-42S.

22. de OLIVEIRA, Guilherme José Pimentel Lopes, et al. "Reparo ósseo induzido por diferentes substitutos de enxerto ósseo em defeitos de tamanho crítico na calvária de ratos." Brazilian Journal of Implantology and Health Sciences (ISSN 2674-8169) 2.9 (2020): 28-44. 
23. Aludden HC, Mordenfeld A, Hallman M, et al. Lateral ridge augmentation with Bio-Oss alone or Bio-Oss mixed with particulate autogenous bone graft: a systematic review. Int J Oral Maxillofac Sur. 2017;46(8):1030-1038.

24. Elnayef B, Porta C, Suárez-López Del Amo F, et al. The Fate of Lateral Ridge Augmentation: A Systematic Review and MetaAnalysis. Int J Oral Maxillofac Implants 2018;33(3):622-635.

25. Chavda S, Levin L. Human Studies of Vertical and Horizontal Alveolar Ridge Augmentation Comparing Different Types of Bone Graft Materials: A Systematic Review. J Oral Implantol 2018;44(1):74-84.

26. Al-Nawas B, Schiegnitz E. Augmentation procedures using bone substitute materials or autogenous bone - a systematic review and meta-analysis. Eur J Oral Implantol. 2014 Summer; 7 Suppl 2:S219-34.

27. Starch-Jensen T, Mordenfeld A, Becktor JP, Jensen SS. Maxillary Sinus Floor Augmentation With Synthetic Bone Substitutes Compared With Other Grafting Materials: A Systematic Review and Meta-analysis. Implant Dent 2018; 27(3):363-374.

28. Silva, Claudio Marques, Regina Souza Ferreira, and Leandro Silva Marques. "Estudo clínico prospectivo, randomizado e controlado para comparar as alterações do tecido rígido após a preservação do alvéolo usando aloplastos, xenoenxertos vs sem enxerto: achados clínicos e histológicos." Brazilian Journal of Implantology and Health Sciences 1.4 (2019): 0117.

29. Khoury F, Keller P, Keeve PL. Stability of Grafted Implant Placement Sites After Sinus Floor Elevation Using a Layering Technique: 10-Year Clinical and Radiographic Results. Int J Oral Maxillofac Implants 2017;32(5):1086-1096.

30. Kim YK, Kim SG. A Retrospective Analysis of the Retreatment of Failed Sinus Bone Grafts. Implant Dent 2016;25(3):450-4.

31. Ahmed MS, Askar NA. Combined bony closure of oroantral fistula and sinus lift with mandibular bone grafts for subsequent dental implant placement. Oral Surg Oral Med Oral Pathol Oral Radiol Endod 2011;111(4):e8-14.

32. Corbella S, Taschieri S, Weinstein R, Del Fabbro M. Histomorphometric outcomes after lateral sinus floor elevation procedure: a systematic review of the literature and metaanalysis. Clin Oral Implants Res 2016;27(9):1106-22.

33. Rammelsberg, Peter, and Julia Pahle. "Ganho ósseo apical a longo prazo após Instalação do implante combinado com elevação do seio maxilar sem enxerto." Brazilian Journal of Implantology and Health Sciences 2.8 (2020): 03-25. 
34. Esposito M, Grusovin MG, Coulthard P, Worthington HV. The efficacy of various bone augmentation procedures for dental implants: A Cochrane systematic review of randomized controlled clinical trials. Int J Oral Maxillofac Implants 2006;21: 696-710.

35. Tallarico M, Meloni SM, Xhanari E, et al. Minimally Invasive Sinus Augmentation Procedure Using a Dedicated Hydraulic Sinus Lift Implant Device: A Prospective Case Series Study on Clinical, Radiologic, and Patient-Centered Outcomes. Int J Periodontics Restorative Dent 2017;37:125-135.

36. Vallet-Regí, Maria, Maria-Pau Ginebra, and Sandra C. Cifuentes. "Enxerto ósseo autógeno com dentes: uma revisão de literatura." Brazilian Journal of Implantology and Health Sciences 1.5 (2019): 90-100.

37. Schwartz-Arad D, Levin L. Multitier technique for bone augmentation using intraoral autogenous bone blocks. Implant Dent 2007;16:5-12. 38. Wen B, Shafer D, Schleier P, et al. Implant-guided supracrestal alveolar bone growth using scaffolds, BMP-2, and novel scaffold-retaining device. Clin Oral Implants Res. 2017;28:1411- 1420 